\title{
Cost-benefit analysis of the rubella vaccination in Japan to prevent congenital rubella syndrome: analyses from three perspectives
}

\author{
Tomoya Itatani ${ }^{1,2 *}$, Chika Honda ${ }^{3}$, Kazuo Hayakawa ${ }^{4}$ and Kaoru Konishi ${ }^{2}$ \\ ${ }^{1}$ Faculty of Health Sciences, Institute of Medical, Pharmaceutical and Health Sciences, Kanazawa University, Japan \\ ${ }^{2}$ Division of Health Science, Graduate School of Medicine, Osaka University, Japan \\ ${ }^{3}$ Center for Twin Research, Graduate School of Medicine, Osaka University, Japan \\ ${ }^{4} \mathrm{Mie}$ Prefectural College of Nursing, Japan
}

\begin{abstract}
In Japan, the number of reports of rubella has increased since 2012, with 14,344 cases being reported in 2013. Rubella infection in a first-trimester pregnant woman could result in congenital rubella syndrome (CRS), which causes serious complications. Many municipalities across the country have implemented programs to control the spread, such as offering a subsidy for the vaccination. The aim of this study is to evaluate the vaccination program for a couple planning pregnancy. We defined two different vaccination models-one for couples and one for females only-in order to compare cases of the program. Economic evaluation was conducted by calculating the benefit-cost ratio (BCR) and net present value (NPV), analyzing from three perspectives: of the society, of the payer for healthcare service, and of the healthcare service recipient. For the base case analysis, rubella cases in 5,564 men and 1,727 women and 34 CRS cases were estimated to have been averted. The BCRs of the couples' program for society was 0.27 , and the NPV estimates were approximately $-6,111$ million yen. The BCRs of the females-only program for society was 0.37. If the price difference between vaccine cost and subsidy is 1,189 yen, there is no effective cost value for the couples' program from the recipient's perspective. Incidence, vaccination costs, and subsidy were relatively sensitive parameters. Overall, the female program was preferable to the couples' program.
\end{abstract}

\section{Introduction}

In Japan, a rubella epidemic used to occur once in every five-year period; however, epidemics have been averted since the Preventive Vaccination Law was revised in 1994 [1]. Nevertheless, the number of reports has increased again since 2012. In 2013, 14,344 cases of rubella were reported, which is the largest number of cases reported after the system changed from a sentinel event report to a total number report [2]. This epidemic was characterized by a high ratio of male patients among the infected [3]; the trigger of the epidemic is thought to be an adult male who traveled to Asia during a large-scale rubella epidemic in 2011 [4]. In addition, the routine rubella vaccination that began in 1997 only targeted middle-school girls until the revision of the Vaccination Law; therefore, the males of this generation have low immunity against rubella [5]. According to the survey conducted in 2012, there was no difference in the antibody prevalence rate between males and females under 20 years old who were vaccinated, whereas coverage and antibody prevalence rate were lower in males 20 years of age or older. This tendency was more obvious in the generation that was 30 years or older, where only females were vaccinated [6]. In many countries other than Japan, adolescent female have been selectively targeted for rubella vaccination, thus the percentage of seronegative for rubella antibodies was higher in young adult males [7]. Although rubella can generally be considered to cause relatively asymptomatic mild infection, serious complications such as encephalitis, thrombocytopenia, and hemolytic anemia are sometimes reported [8-10], calling for vigilance for outbreaks. Rubella among adults is likely to be severe, with $30 \%$ of adult patients reportedly requiring hospitalization [11].
Rubella infection in first-trimester pregnant women can result in congenital rubella syndrome (CRS), which causes serious complications such as heart disease, cataracts, hearing loss, liver splenomegaly, thrombocytopenia, diabetes, developmental delay, mental retardation, and small eye [12]. Thirty-two cases of CRS were reported in the epidemic year of 2013 [13]. The Ministry of Health, Labour and Welfare has deployed enlightenment programs for the prevention of a rapid increase in cases of rubella [14]. Whereas children are currently inoculated with the measles-rubella (MR) vaccine between one to two years of age and again between five to six years of age routinely in Japan, the government recommends additional rubella vaccination for couples who plan to conceive in order to prevent CRS. In response to this announcement, many municipalities across the country have implemented prevention programs, such as offering a subsidy for the rubella vaccination, often targeting women who are planning to get pregnant and their spouses.

In Japan, the recent increase in security costs has added importance of efficient use of the social security allowance. An economic analysis of the vaccination program should be conducted in order to improve efficiency. Therefore, the aims of this study are to conduct a cost-benefit

Correspondence to: Tomoya Itatani, Division of Nursing, Faculty of Health Science Institute of Medical, Pharmaceutical and Health Sciences, Kanazawa University, Japan; E-mail: itatani@mhs.mp.kanazawa-u.ac.jp

Key words: cost-benefit analysis, rubella, vaccination

Received: March 04, 2016; Accepted: April 08, 2016; Published: April 13, 2016 
analysis of the rubella vaccination for a couple planning pregnancy and to evaluate the program.

\section{Methods}

\section{Decision model structure and parameters}

We constructed the model assuming additional rubella vaccination for couples who plan to conceive. We adopted a state-transition Markov model as the decision model to estimate the number of rubella patients. The structure of the model is shown in Figure 1. The model predicts the number of patients by defining multiple possible states of the cohort and simulating the dynamics of the cohort transiting between states. Most of the municipalities across the country target women who are planning to get pregnant and their spouses for the vaccination program. However, considering the occasionally fatal outcomes of CRS, a program targeted only females may also be considered to cope with the limited financial resources. Therefore, we constructed a program model that targets only females (the females program) in addition to the model targeting couples (the couples program) and compared the effects of the programs being implemented and not implemented, respectively. We set the cycle length as one year and followed 20 cycles. We assumed one million as the number of births by referring to the national vital statistics [15], and that the parents of the babies born were the target of the vaccination program. Therefore, the hypothetical cohort in this model is 2 million people, including 1 million men and 1 million women. We assumed the age of the cohort to be 20-40 years, considering the reproductive and parenting age of the hypothetical cohort. Cost-benefit analysis has an advantage over costeffectiveness and cost-utility analysis, as it does not require complete data on all alternatives [16]. This study aimed to compare a program over a current one thus we did not take into account quality-adjusted life-years, incremental cost-effectiveness ratio, and other indices accounting for quality of life.

The parameters are described in Table 1 . The parameters used in this model were assumed by referring to existing research and domestic data. We assumed the initial vaccine efficacy to be $95 \%$ based on Centers for Disease Control and Prevention (CDC) [17]. Assuming that the immunity acquired by vaccination sustains for life, or we did not consider the waning of the immunity acquired by the rubella vaccination [17]. It is generally considered that most adverse events following the measles-mumps-rubella (MMR) vaccine are attributable to the measles component, and the rubella vaccine is very safe [17]. The severe adverse events associated with the rubella vaccine, such as thrombocytopenia and encephalitis, rarely occur [18]. We determined the incidence of severe adverse events associated with the vaccine based on reports of incidence from domestic data [19].

\section{Cost of vaccination program}

We assumed the vaccine cost to be 6,000 yen per participant based on public information provided by medical institutions. To estimate the costs of the overall vaccination program, we multiplied the cost of one dose by the number of participants. Medical costs and indirect costs of adverse events were included in the costs of the vaccination program.

Since, to our Knowledge, there is no literature on the coverage of the rubella vaccine among adults, we referred to the literature on other vaccination programs for children in order to assume coverage.

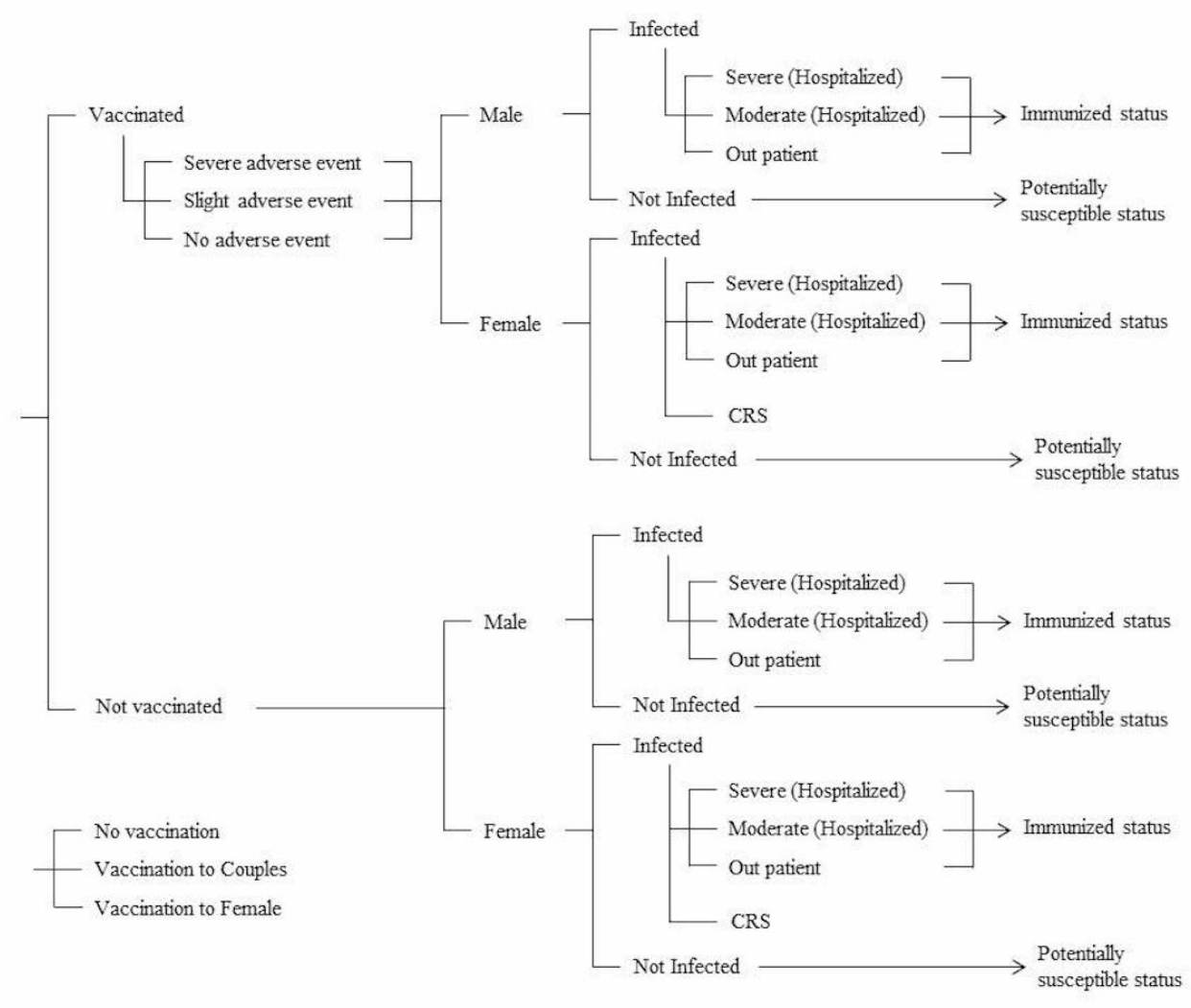

Figure 1. Markov model. 
Table 1. Parameters.

\begin{tabular}{|c|c|c|c|}
\hline Parameter & Value & Unit & References \\
\hline Hypothetical cohort & 2 million & People & Based on Japanese population \\
\hline Time horizon & 20 & Years & Assumed \\
\hline Incidence (males) & 42 & Per 100,000 & {$[20]$} \\
\hline Incidence (females) & 13 & Per 100,000 & {$[20]$} \\
\hline Initial vaccine efficacy & 95 & $\%$ & {$[17]$} \\
\hline Antibody prevalence rate (males) & $73-84$ & $\%$ & {$[20]$} \\
\hline Antibody prevalence rate (females) & 95 & $\%$ & {$[20]$} \\
\hline Cost of one vaccination & 6000 & Yen & Assumed \\
\hline Subsidy for one vaccination & 3000 & Yen & Assumed \\
\hline Coverage & 70 & $\%$ & {$[21]$} \\
\hline Indirect cost (males) & 7033 & Yen/day & {$[22]$} \\
\hline Indirect cost (females) & 6032 & Yen/day & {$[22]$} \\
\hline Lifetime income (discounted) & 49,168 & Thousand yen & {$[22]$} \\
\hline Deduction of living expenses & 30 & $\%$ & Assumed \\
\hline Discount rate & 3 & $\%$ & [23] \\
\hline \multicolumn{4}{|l|}{$\begin{array}{l}\text { Disease outcomes and medical costs } \\
\text { (Rubella) }\end{array}$} \\
\hline \multicolumn{4}{|l|}{ Severity of rubella infection } \\
\hline Severe (Hospitalized) & 0.9 & $\%$ & {$[11][24]$} \\
\hline Moderate (Hospitalized) & 66.1 & $\%$ & {$[24]$} \\
\hline Mild (Outpatient) & 33.9 & $\%$ & {$[24]$} \\
\hline \multicolumn{4}{|l|}{ Medical costs for rubella infection } \\
\hline Severe (Hospitalized) & $450-1,980$ & Thousand Yen & {$[25]$} \\
\hline Moderate (Hospitalized) & 320 & Thousand Yen & {$[25]$} \\
\hline Mild (Outpatient) & 4 & Thousand Yen & {$[25]$} \\
\hline \multicolumn{4}{|l|}{ Period of hospitalization or homecare for rubella infection } \\
\hline Severe (Hospitalized) & $15-36$ & Days & {$[26]$} \\
\hline Moderate (Hospitalized) & 11 & Days & {$[26]$} \\
\hline Mild (Outpatient) & 5 & Days & {$[26]$} \\
\hline \multicolumn{4}{|l|}{$\begin{array}{l}\text { Disease outcomes and medical costs } \\
\text { (CRS) }\end{array}$} \\
\hline Incidence of CRS due to rubella infection during pregnancy & 23.9 & $\%$ & {$[13][27]$} \\
\hline Medical costs for CRS & $250-10,450$ & Thousand Yen & {$[12][25][28]$} \\
\hline Mortality of CRS infants & 37.0 & $\%$ & [28] \\
\hline Total loss of productivity due to CRS complications & 31.5 & $\%$ & [29] \\
\hline Half loss of productivity due to CRS complications & 31.5 & $\%$ & [29] \\
\hline Lost productivity caused by infant death due to CRS & 70,240 & Thousand Yen & {$[22]$} \\
\hline \multicolumn{4}{|l|}{$\begin{array}{l}\text { Disease outcomes and medical costs } \\
\text { (vaccine adverse event) }\end{array}$} \\
\hline Incidence of severe adverse event due to vaccine & 0.0002 & $\%$ & [19] \\
\hline Medical costs for severe adverse event due to vaccine & 198 & Ten thousand Yen & {$[25]$} \\
\hline
\end{tabular}

According to the report on vaccination programs for children, rubella vaccine coverage among children has been sustained at approximately $90 \%$ [21]. It is likely to be difficult for adult vaccination programs to achieve coverage as high as child vaccination programs, as public health centers encourage parents to vaccinate their children. This is implied by the fact that even the highest coverage among adults is that for the influenza vaccine, which is nonetheless no greater than $40 \%$ [21]. So, we assumed the coverage of the rubella vaccine among adults to be $70 \%$ for the base case analysis and performed sensitivity analysis in the range of 40 to $100 \%$ as described below.

\section{Incidence and severity of rubella}

Incidence was estimated from the infection surveillance data. Based on the chronological report of people of aged 20-40 years, we assumed the incidence among males and females separately [20]. The immunity of males is lower than that of females. While the prevalence of antibodies in females was $95 \%$ or more in their 20 s and 30 s, that in males was $90 \%$ in their 20 s and $73-84 \%$ in their 30 s [30], implying that antibody prevalence in males is lower than that in females, and males are more likely to transit to the infected state than are females. Both males and females transit to the immunized state after infection; therefore, they will not transit to the re-infected state in this model.

Since severe platelets purpura, acute encephalitis, meningitis, and liver failure were complications of rubella reported among adults [24], we defined the occurrence of these conditions as severe cases in this study. Except for these severe cases, we defined cases that required hospitalization as "moderate" and cases that required outpatient therapy as "mild" [11]. Moderate and mild cases included those with symptoms of conjunctivitis, headache, sore throat, arthralgia, cough, lymphadenopathy, and rash [11].

We estimated the incidence of CRS based on the incidence in each trimester of rubella-infected pregnant women [27]. Targeting couples planning pregnancy with a vaccination program in our study, we assumed that all women would give birth in the first year of the analysis. We did not consider pregnancies that were interrupted or multiple 
births. For the second year of our analysis or later, we estimated the number of births with CRS from the age-specific fertility rate and the incidence of CRS. Since infection in pregnancy could lead to CRS even if the infection is subclinical, we took this into consideration for the estimation [31].

\section{Medical and indirect costs}

We multiplied the frequency of occurrence of each symptom by the associated medical expenses, obtained by referring to the Survey on Medical Benefit Expenditure, in order to calculate the costs of the whole vaccination program [25]. Further, assuming the duration of hospitalization for each symptom based on data obtained from the Patient Survey, we estimated the indirect costs as salary loss due to hospitalization [26]. Gender wage censuses were used to estimate indirect costs [22]. Likewise, each symptom of CRS, the associated medical expenses, and the indirect costs were estimated from the Survey on Medical Benefit Expenditure and the Patient Survey.

A discount rate of $3 \%$ per year was used in this study [23].

\section{Costs related to mortality and sequela of CRS-affected infants}

We calculated the lost productivity due to CRS mortality by applying the $3 \%$ discount rate to the average lifetime income [22], using a $30 \%$ deduction for living expenses. According to previous studies, we assumed productivity losses of $0 \%, 50 \%$, and $100 \%$ due to CRS sequela, and combined these with lost productivity [29].

\section{Economic evaluation of the program}

Estimation of the costs of the vaccination program is described above.

The benefits of implementing the vaccination program were calculated by multiplying the number of cases averted by both medical costs and indirect costs. Medical costs of CRS and the lost productivity due to sequela were included in the calculation.

Economic evaluation was conducted using the benefit-cost ratio (BCR) and the net present value (NPV).

\section{Analysis perspective}

According to the guideline established by the Advisory Committee on Immunization Practices (ACIP), economic evaluations of vaccination programs should be conducted from the perspective of the society [32]. From the societal perspective, all medical expenditures incurred for rubella treatment and indirect costs are included in the costs of the program, and all averted medical expenditures, indirect costs, and lost productivity are included in the benefits of the program. In order to consider the administrative and the public views, we conducted the analysis form the following two perspectives.

We defined the "payer's perspective" as the perspective of the payer of the cost for healthcare service, including the agencies implementing the program. From the payer's perspective, the costs include the subsidy provided for vaccination and $70 \%$ of the medical expenditure for the treatment of the rubella infection and vaccine adverse events, which is covered under public health insurance in Japan. While $80 \%$ of the medical expenditure for preschoolers is paid by public health insurance in Japan, local governments pay the remaining 20\%. In this study, all medical expenditures for CRS-affected infants are included in the costs from the payer's perspective.

We defined the "recipient's perspective" as the perspective of subjects who have medical insurance. From the recipient's perspective, the costs of the vaccination program include $30 \%$ of the medical expenditure for treatment of the rubella infection and vaccine adverse event, which is required as a copayment by adults. Indirect costs from the recipient's perspective include costs such as salary loss due to hospitalization. Since the treatment of CRS-affected infants is practically free from the recipient's perspective, as described above, the costs of vaccination do not include copayment for medical expenditure on treatment of infants. The lost productivity that results from CRS sequela or deaths was assumed to be borne by the recipient.

\section{Sensitivity analysis}

We performed sensitivity analysis on the parameters of cohort size, incidence, initial vaccine efficacy, vaccination cost, subsidy, coverage, medical cost, indirect cost, and discount rate. We conducted sensitivity analysis from the three perspectives described above, and evaluated the impact of each parameter.

\section{Results}

\section{Number of rubella and CRS cases averted by the vaccination program}

The numbers of rubella and CRS cases averted are shown in Table 2. An estimated 5,564 rubella cases in men and 1,727 in women were averted in the base case analysis of the program for couples, and 1,727 rubella cases in women were averted by the program for females. Thirty-four cases of CRS were also estimated as having been averted by both the program for couples and that for females.

\section{Benefit-cost ratio and net present value from three perspectives}

The upper half of the Table 3 shows the couples program result. The BCRs from the three perspectives were $0.13,0.15$, and 0.11 , respectively. In addition, the NPV estimates were approximately $-7,302$ million yen, $-3,578$ million yen, and $-3,726$ million yen, respectively, as shown in Table 3.

Similarly, the lower half of Table 3 summarizes the estimates for the females program. The BCRs were $0.09,0.12$, and 0.05 , respectively. In addition, the NPV estimates were approximately $-3,833$ million yen, $-1,840$ million yen, and $-1,994$ million yen, respectively.

The lost productivity was calculated by adding economic loss resulting from deaths among CRS-affected infants and losses of productivity due to sequela. While lost productivity was not considered from the payer's perspective, it was the same from the societal perspective and the recipient's perspective, and estimated to be approximately 1,190 million yen.

The estimated BCRs of the program for couples from the three perspectives, including lost productivity, were $0.27,0.15$, and 0.40 , respectively. Additionally, the NPV estimates were $-6,111$ million yen, $-3,578$ million yen, and $-2,534$ million yen, respectively.

Similarly, the estimated BCRs of the program for females from the three perspectives, including lost productivity, were $0.37,0.12$, and 0.62 , respectively. Additionally, the NPV estimates were $-2,642$ million yen, $-1,840$ million yen, and -803 million yen, respectively. These results show that the females program shows higher BCR than that with couples program. 
Table 2. Number of Cases of Rubella and CRS Averted by Program.

\begin{tabular}{|l|l|c|c|c|}
\hline & & Without program (1) & With program (2) \\
\hline For couples & Males & 8,368 & 2,804 \\
\hline & Females & 2,597 & 870 \\
\hline & CRS & 51 & 1,727 \\
\hline & Males & 8,368 & 34 \\
\hline & Females & 2,597 & 8,368 \\
\hline & CRS & 51 & 8,70 \\
\hline
\end{tabular}

Table 3. BCR and NPV from Three Perspectives.

\begin{tabular}{|c|c|c|c|c|}
\hline & (Perspective of analysis) & Societal perspective & Payer's perspective $^{\mathrm{d}}$ & Recipient's perspective ${ }^{e}$ \\
\hline \multirow[t]{7}{*}{ For couples } & Cost (1) & $8,406,323,252$ & $4,204,426,277$ & $4,203,793,951$ \\
\hline & Benefit (2) & $1,104,051,400$ & $626,216,300$ & $477,835,100$ \\
\hline & $\mathrm{BCR}(2) /(1))^{\mathrm{a}}$ & 0.13 & 0.15 & 0.11 \\
\hline & NPV (2) - (1) $)^{b}$ & $-7,302,271,853$ & $-3,578,209,977$ & $-3,725,958,851$ \\
\hline & Saved cost of lost productivity (3) & $1,190,982,961$ & 0 & $1,190,982,961$ \\
\hline & $\begin{array}{l}\text { BCR including the saved cost of lost productivity } \\
(((2)+(3) /(1))\end{array}$ & 0.27 & 0.15 & 0.40 \\
\hline & $\begin{array}{l}\text { NPV including the saved cost of lost productivity } \\
((2)+(3)-(1))\end{array}$ & $-6,111,288,891$ & $-3,578,209,977$ & $-2,534,975,890$ \\
\hline \multirow[t]{7}{*}{ For females Only } & Cost (1) & $4,203,137,161$ & $2,102,196,013$ & $2,101,882,297$ \\
\hline & Benefit (2) & $369,895,634$ & $262,071,645$ & $107,823,989$ \\
\hline & BCR (2)/(1)) & 0.09 & 0.12 & 0.05 \\
\hline & NPV (2) - (1)) & $-3,833,241,527$ & $-1,840,124,368$ & $-1,994,058,308$ \\
\hline & Saved cost of lost productivity (3) & $1,190,982,961$ & 0 & $1,190,982,961$ \\
\hline & $\begin{array}{l}\text { BCR including the saved cost of lost productivity } \\
((2)+(3) /(1))\end{array}$ & 0.37 & 0.12 & 0.62 \\
\hline & $\begin{array}{l}\text { NPV including the saved cost of lost productivity } \\
(((2)+(3))-(1))\end{array}$ & $-2,642,258,566$ & $-1,840,124,368$ & $-803,075,346$ \\
\hline
\end{tabular}

aBCR: Benefit-cost ratio

${ }^{b} \mathrm{NPV}$ : Net present value

'Saved cost of lost productivity: the cost of

productivity saved by avoiding infant death due to

CRS

'Payer's perspective: the perspective of the payer of

the cost for healthcare services

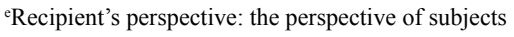

who have medical insurance

\section{Sensitivity analysis}

The results of the sensitivity analysis in the couples program considering lost productivity are shown in Table 4.

Incidence was analyzed as ranging from 0.2 to 5.0 times the basic value. In cases of 5.0 times the basic value, the BCR from the societal perspective was 1.36 and the NPV was 3,010 million yen. From the recipient's perspective, the estimate of the BCR was 1.96, and the estimate of the NPV was 4,110 million yen. The BCR from the payer's perspective was 0.74 .

When vaccination cost was 3,000 yen, benefits were significantly higher than the costs from the recipient's perspective because the cost of the vaccination was equal to the subsidy, and the recipients had to incur no additional expense. Similarly, when the subsidy was 6,000 yen, the recipient had to incur no additional expense, and the benefits were significantly higher than the costs from the recipient's perspective.

By contrast, when the subsidy was zero, benefits were significantly higher than the costs from the payer's perspective because the majority of the costs for the payer were used to provide the subsidy for vaccination.

The NPV from the societal perspective was estimated to range from approximately $-3,492$ million yen to $-8,730$ million yen, with the sensitivity analysis of coverage ranging from 40 to $100 \%$. Like the sensitivity analysis of coverage, the BCR did not change in any perspective.

Medical costs were analyzed as ranging from 0.2 to 5.0 times the basic value, and the BCR from the societal perspective varied from 0.19 to 0.67 . The BCR from the societal perspective varied from 0.25 to 0.40 with the sensitivity analysis of indirect costs ranging from 0.2 to 5.0 times the basic value. The sensitivity analysis of the initial vaccine efficacy ranged from 90 to $100 \%$, revealing that BCR and NPV did not vary significantly.

The range of discount rates considered in the analysis was 0 to $5 \%$. When the discount rate was zero, benefits exceeded costs from the recipient's perspective and the BCR was 1.07. In this case, the NPV was approximately 315 million yen.

The results of the sensitivity analysis of parameters in the females program considering lost productivity are shown in Table 5. Comparing the two programs, the BCR of the females program was higher than that of the couples program from the societal and recipient's perspective for all parameters except discount rate. From the payer's perspective, the BCR of the couples program was slightly higher than that of the females program from all perspectives. Conducting the sensitivity analysis on discount rate, the BCRs of the programs for couples and females were 
not sensitive from the payer's perspective, but were sensitive from the societal and recipient's perspectives.

Additionally, the values for each parameters exceeding 1.0 for BCR are shown in Tables 4 and 5 .

\section{Discussion}

Although vaccination programs involve a substantial expense, they are effective healthcare policy to prevent infectious disease. Since the rubella vaccination program targeting couples planning pregnancy has already been implemented in a number of municipalities in Japan, it is important to analyze economic dynamics in order to extract the maximum effectiveness with limited financial resources [33]. Furthermore, assessing the BCR and NPV in specific parameter settings by performing sensitivity analysis is important to compare the programs.

\section{Analysis for basic parameter setting}

In our model, the costs of the entire vaccination program for couples were more than 8.4 billion yen from the societal perspective. However, approximately 1.1 billion yen of medical costs and 1.2 billion yen of the cost of lost productivity due to CRS were prevented by the program. Therefore, the effective value of the entire vaccination program cost was approximately 6.1 billion yen, which was about $72 \%$

Table 4. Sensitivity Analysis of BCR and NPV Including the Saved Cost of Lost Productivity

\begin{tabular}{|c|c|c|c|c|c|c|c|}
\hline \multirow{3}{*}{$\begin{array}{l}\text { Parameter } \\
\text { (Unit) }\end{array}$} & \multirow[t]{3}{*}{ Range } & \multicolumn{2}{|c|}{ Societal perspective } & \multicolumn{2}{|c|}{ Payer's perspective $^{d}$} & \multicolumn{2}{|c|}{ Recipient's perspective $^{\mathrm{e}}$} \\
\hline & & $\left(\right.$ (BCR $^{\mathrm{b}}$ & $(\mathrm{NPV})^{\mathrm{c}}$ & (BCR) & (NPV) & (BCR) & (NPV) \\
\hline & & \multicolumn{6}{|c|}{ [Parameter value as $1 \leqq \mathrm{BCR}]$} \\
\hline \multirow{3}{*}{\begin{tabular}{|l} 
Cohort Size \\
(Million people)
\end{tabular}} & 250 & 0.27 & $-7,639,111,114$ & 0.15 & $-4,472,762,471$ & 0.40 & $-3,168,719,862$ \\
\hline & 150 & 0.27 & $-4,583,466,668$ & 0.15 & $-2,683,657,483$ & 0.40 & $-1,901,231,917$ \\
\hline & & \multicolumn{2}{|l|}{-} & \multicolumn{2}{|l|}{-} & \multicolumn{2}{|l|}{-} \\
\hline \multirow{3}{*}{$\begin{array}{l}\text { Incidence } \\
\text { (Times) }\end{array}$} & 5.0 & 1.36 & $3,010,381,534$ & 0.74 & $-1,101,810,374$ & 1.98 & $4,110,294,933$ \\
\hline & 0.2 & 0.05 & $-7,946,843,726$ & 0.03 & $-4,078,952,850$ & 0.08 & $-3,869,787,851$ \\
\hline & & \multicolumn{2}{|l|}{3.68} & \multicolumn{2}{|l|}{6.80} & \multicolumn{2}{|l|}{2.53} \\
\hline \multirow{3}{*}{$\begin{array}{l}\text { Initial Vaccine Efficacy } \\
(\%)\end{array}$} & 100 & 0.29 & $-5,990,497,609$ & 0.16 & $-3,545,251,224$ & 0.42 & $-2,447,143,360$ \\
\hline & 90 & 0.26 & $-6,232,080,173$ & 0.14 & $-3,611,168,730$ & 0.38 & $-2,622,808,419$ \\
\hline & & \multicolumn{2}{|l|}{-} & \multicolumn{2}{|l|}{-} & \multicolumn{2}{|l|}{-} \\
\hline \multirow{3}{*}{$\begin{array}{l}\text { Vaccine Cost } \\
\text { (Yen) }\end{array}$} & 9000 & 0.18 & $-10,311,288,891$ & 0.15 & $-3,578,209,977$ & 0.20 & $-6,734,975,890$ \\
\hline & 3000 & 0.55 & $-1,911,288,891$ & 0.15 & $-3,578,209,977$ & 439.86 & $1,665,024,110$ \\
\hline & & \multicolumn{2}{|l|}{1635} & \multicolumn{2}{|l|}{-} & \multicolumn{2}{|l|}{4,189} \\
\hline \multirow{3}{*}{$\begin{array}{l}\text { Subsidy } \\
\text { (Yen) }\end{array}$} & 6000 & 0.27 & $-6,111,288,891$ & 0.07 & $-7,778,209,977$ & 439.86 & $1,665,024,110$ \\
\hline & 0 & 0.27 & $-6,111,288,891$ & 141.48 & $621,790,023$ & 0.20 & $-6,734,975,890$ \\
\hline & & \multicolumn{2}{|l|}{-} & \multicolumn{2}{|l|}{444} & \multicolumn{2}{|l|}{4,811} \\
\hline \multirow{3}{*}{$\begin{array}{l}\text { Coverage } \\
(\%)\end{array}$} & 100 & 0.27 & $-8,730,412,702$ & 0.15 & $-5,111,728,539$ & 0.40 & $-3,621,394,128$ \\
\hline & 40 & 0.27 & $-3,492,165,081$ & 0.15 & $-2,044,691,415$ & 0.40 & $-1,448,557,651$ \\
\hline & & \multicolumn{2}{|l|}{-} & \multicolumn{2}{|l|}{-} & \multicolumn{2}{|l|}{ - } \\
\hline Medical Cost & 5.0 & 0.67 & $-2,788,478,317$ & 0.74 & $-1,073,344,779$ & 0.59 & $-1,717,030,514$ \\
\hline & 0.2 & 0.19 & $-6,775,851,006$ & 0.03 & $-4,079,183,017$ & 0.36 & $-2,698,564,965$ \\
\hline & & 8.4 & & 6.8 & & 13.4 & \\
\hline Indirect Cost & 5.0 & 0.40 & $-5,017,893,868$ & 0.15 & $-3,578,209,977$ & 0.66 & $-1,441,580,866$ \\
\hline & 0.2 & 0.25 & $-6,329,967,896$ & 0.15 & $-3,578,209,977$ & 0.34 & $-2,753,654,895$ \\
\hline & & 23.4 & & - & & 10.3 & \\
\hline Discount Rate & 5 & 0.19 & $-6,842,330,859$ & 0.13 & $-3,649,117,902$ & 0.24 & $-3,195,109,932$ \\
\hline & 0 & 0.63 & $-3,113,935,826$ & 0.18 & $-3,430,755,069$ & 1.07 & $314,922,267$ \\
\hline & & - & & - & & 0 & \\
\hline
\end{tabular}

a Saved cost of lost productivity: the cost of

productivity saved by avoiding infant death due to

CRS

${ }^{b} B C R$ : Benefit-cost ratio

'NPV: Net present value

'Payer's perspective: the perspective of the payer of

the cost for healthcare services

'Recipient's perspective: the perspective of subjects

who have medical insurance 
Table 5. Sensitivity Analysis of BCR and NPV Including the Saved Cost of Lost Productivity (Program for Females Only).

\begin{tabular}{|c|c|c|c|c|c|c|c|}
\hline \multirow{3}{*}{$\begin{array}{l}\text { Parameter } \\
\text { (Unit) }\end{array}$} & \multirow[t]{2}{*}{ Range } & \multicolumn{2}{|c|}{ Societal perspective } & \multicolumn{2}{|c|}{ Payer's perspective $^{d}$} & \multicolumn{2}{|c|}{ Recipient's perspective $^{\mathrm{e}}$} \\
\hline & & $(\mathrm{BCR})^{\mathrm{b}}$ & $(\mathbf{N P V})^{\mathrm{c}}$ & (BCR) & (NPV) & (BCR) & $(\mathbf{N P V})$ \\
\hline & & \multicolumn{6}{|c|}{ [Parameter value as $1 \leq \mathrm{BCR}$ ] } \\
\hline \multirow{3}{*}{$\begin{array}{l}\text { Cohort Size } \\
\text { (Million people) }\end{array}$} & 250 & 0.37 & $-3,302,823,207$ & 0.12 & $-2,300,155,460$ & 0.62 & $-1,003,844,183$ \\
\hline & 150 & 0.37 & $-1,981,693,924$ & 0.12 & $-1,380,093,276$ & 0.62 & $-602,306,510$ \\
\hline & & \multicolumn{2}{|l|}{-} & \multicolumn{2}{|l|}{-} & \multicolumn{2}{|l|}{-} \\
\hline \multirow{3}{*}{$\begin{array}{l}\text { Incidence } \\
\text { (Times) }\end{array}$} & 5.0 & 1.86 & $3,594,788,766$ & 0.62 & $-794,511,157$ & 3.09 & $4,388,358,775$ \\
\hline & 0.2 & 0.07 & $-3,890,909,567$ & 0.02 & $-2,049,760,226$ & 0.12 & $-1,842,090,489$ \\
\hline & & \multicolumn{2}{|l|}{2.70} & \multicolumn{2}{|l|}{8.05} & \multicolumn{2}{|l|}{1.62} \\
\hline \multirow{3}{*}{$\begin{array}{l}\text { Initial Vaccine Efficacy } \\
(\%)\end{array}$} & 100 & 0.39 & $-2,560,107,061$ & 0.13 & $-1,826,331,123$ & 0.65 & $-734,717,085$ \\
\hline & 90 & 0.35 & $-2,724,410,071$ & 0.12 & $-1,853,917,612$ & 0.59 & $-871,433,607$ \\
\hline & & \multicolumn{2}{|l|}{-} & \multicolumn{2}{|l|}{-} & \multicolumn{2}{|l|}{-} \\
\hline \multirow{3}{*}{$\begin{array}{l}\text { Vaccine Cost } \\
\text { (Yen) }\end{array}$} & 9000 & 0.25 & $-4,742,258,566$ & 0.12 & $-1,840,124,368$ & 0.31 & $-2,903,075,346$ \\
\hline & 3000 & 0.74 & $-542,258,565$ & 0.12 & $-1,840,124,368$ & 690.01 & $1,296,924,654$ \\
\hline & & \multicolumn{2}{|l|}{2,225} & \multicolumn{2}{|l|}{-} & \multicolumn{2}{|l|}{4,852} \\
\hline \multirow{3}{*}{$\begin{array}{l}\text { Subsidy } \\
\text { (Yen) }\end{array}$} & 6000 & 0.37 & $-2,642,258,566$ & 0.06 & $-3,940,124,368$ & 690.01 & $1,296,924,654$ \\
\hline & 0 & 0.37 & $-2,642,258,566$ & 119.34 & $259,875,632$ & 0.31 & $-2,903,075,346$ \\
\hline & & \multicolumn{2}{|l|}{-} & \multicolumn{2}{|l|}{371} & \multicolumn{2}{|l|}{4,148} \\
\hline \multirow{3}{*}{$\begin{array}{l}\text { Coverage } \\
(\%)\end{array}$} & 100 & 0.37 & $-3,774,655,094$ & 0.12 & $-2,628,749,097$ & 0.62 & $-1,147,250,495$ \\
\hline & 40 & 0.37 & $-1,509,862,038$ & 0.12 & $-1,051,499,639$ & 0.62 & $-458,900,198$ \\
\hline & & \multicolumn{2}{|l|}{-} & \multicolumn{2}{|l|}{-} & \multicolumn{2}{|l|}{-} \\
\hline Medical Cost & 5.0 & 0.67 & $-1,400,274,588$ & 0.62 & $-791,837,786$ & 0.71 & $-609,377,949$ \\
\hline & 0.2 & 0.31 & $-2,890,655,361$ & 0.02 & $-2,049,781,684$ & 0.60 & $-841,814,825$ \\
\hline & & 9.6 & & 8.1 & & 17.6 & \\
\hline Indirect Cost & 5.0 & 0.43 & $-2,404,660,008$ & 0.12 & $-1,840,124,368$ & 0.73 & $-565,476,788$ \\
\hline & 0.2 & 0.36 & $-2,689,778,277$ & 0.12 & $-1,840,124,368$ & 0.60 & $-850,595,058$ \\
\hline & & 47.4 & & - & & 15.1 & \\
\hline Discount Rate & 5 & 0.12 & $-7,433,019,211$ & 0.06 & $-3,940,124,368$ & 0.17 & $-3,493,835,992$ \\
\hline & 0 & 0.51 & $-4,137,242,765$ & 0.06 & $-3,940,124,368$ & 0.95 & $-198,059,545$ \\
\hline & & - & & - & & - & \\
\hline
\end{tabular}

a Saved cost of lost productivity: the cost of

productivity saved by avoiding infant death due to

CRS

${ }^{\mathrm{b} B C R}$ : Benefit-cost ratio

${ }^{\mathrm{N}} \mathrm{NPV}$ : Net present value

'Payer's perspective: the perspective of the payer of

the cost for healthcare services

${ }^{\text {e}}$ Recipient's perspective: the perspective of subjects

who have medical insurance

of the estimated total cost of the program. Thus, the effective value of the program was considerably lower than the estimated total cost of the program, which should be considered in evaluation of vaccination programs.

As the number of participants in the females program was half that of the couples program, the cost was approximately half that of the couples program. From the perspective of preventing adult rubella, the BCR of the program for couples, which includes males, was higher than that of the program for females. However, from the perspective of preventing CRS, the BCR of the females-only program including lost productivity due to CRS mortality was higher than that of the couples program. Therefore, the program for females only was preferable to prevent CRS.

\section{Sensitivity analysis}

Incidence was a sensitive parameter in the programs for couples and for females. It is believed that $15-50 \%$ of rubella cases are subclinical $[17,28]$. Additionally, differential diagnosis with measles is said to be difficult [11]. Considering these facts, the number of individuals infected with rubella is probably higher than the reported number. Greater accuracy of diagnosis and reports is needed in order to enhance the validity of economic analysis.

Vaccine cost was sensitive from the recipient's perspective. When the vaccine cost decreased to 4,189 yen in the program for couples or 4,852 yen in the program for females, the benefits exceeded the costs. When the vaccination cost is lowered, the burden on the subjects becomes lighter. Therefore, coverage is considered to increase with a 
decrease in the vaccination cost. It is desirable to have a low vaccination cost in order to increase coverage. If the price difference between vaccine cost and subsidy is 1,189 yen in the couples program or 1,852 yen in the females-only program, there is no effective value of costs from the recipient's perspective.

On the other hand, subsidy was sensitive from the payer's perspective. The economic burden on the healthcare payer would increase with the subsidy. If the subsidy of the couples program decreases to 444 yen, there is no effective value of cost of the vaccination program, and the healthcare payer has no economic burden. However, if the subsidy were suppressed, coverage would decrease as well. Therefore, considering the balance between subsidy and coverage is important.

The costs of the vaccination program would increase with coverage because the number of subjects being vaccinated would increase. However, the BCR would not change with coverage.

There was no apparent change in the results of the analysis of medical costs and indirect costs from any perspective. This is because severe cases that require substantial medical expenses rarely develop in adult rubella, and indirect costs of salary lost because of hospitalization would not increase with short-term hospitalization.

Discount rate was a sensitive parameter for both the couples program and the females-only program. The BCR of the females-only program in particular tended to decrease when increasing the discount rate. This is because the lost productivity from CRS mortality was calculated from the average lifetime income, which is a sensitive value of the discount rate. Therefore, a policy that affects the adoption of healthcare programs in the long term should be economically evaluated using the discount rate.

\section{Future study}

While not considered in this study, it is thought that cases exist of interrupted pregnancy when rubella is found in early pregnancy. A model considering economic burden due to pregnancy interruption is required in future study.

CRS survivors require special services for day-to-day life, and this cost would be borne by municipalities and health insurance payers. This cost was not considered in the current study; however, in this case, the costs from the payer's perspective of averting rubella cases would be lower than what has been estimated in this study. These points should be considered in future study.

Finally, we evaluated the vaccination program by estimating the costs, the benefits, and the BCR. We also performed sensitivity analysis. However, analysis in this study only considered economic aspects. In subsequent studies, the program should be evaluated from the perspective of utility, and a cost-effectiveness analysis, which is an analytical method that combines economic aspects and effectiveness, should be done.

\section{Conclusion}

Rubella cases in 5,564 men and 1,727 women were estimated to have been averted, as well as 34 cases of CRS. The BCR of the program for couples, including the saved cost of lost productivity due to CRS, was 0.27 , and the NPV was approximately -6.111 million yen from the societal perspective. Further, the BCR of the program for females was 0.34 and the NPV was $-2,642$ million yen from the societal perspective. Incidence, vaccination costs, and subsidy were relatively sensitive parameters. Overall, the vaccination program for females was preferable to that for couples.

\section{Acknowledgments}

We would like to express our gratitude to Prof. Ohkusa (Infectious Disease Surveillance Center National Institute of Infectious Disease), whose comments and suggestions were of great help to this study.

\section{Author contributions}

All authors contributed equally to this manuscript. Tomoya Itatani, and Chika Honda developed the concept. Kazuo Hyakawa, and Kaoru Konishi gave conceptual advice. Tomoya Itatani built the model, analyzed statistical data. Tomoya Itatani, and Chika Honda wrote the manuscript. All authors read and approved the manuscript.

\section{Conflicts of interest}

We report no declaration or conflict of interest.

\section{References}

1. Mitsunobu M (2006) Transition of pediatric infectious disease and vaccination (小児感 染症の変遷と予防接種) 343-350.

2. National Institute of Infectious Diseases (2015) Infectious disease surveillance (感染 症発生動向調査).

3. Centers for Disease Control and Prevention (CDC) (2013) Nationwide rubella epidemic-Japan, MMWR 62: 457-462.

4. National Institute of Infectious Diseases (2013) What is Rubella? (風疹とは).

5. Taya K (2005) The history and future of the rubella vaccination in Japan (わが国に おける風疹予防接種の歴史と今後). Child Health (ちやいるどへルス) 8: 643-648.

6. National Institute of Infectious Diseases (2013) 2012 rubella vaccination status and antibody prevalence - 2012 infection epidemic prediction study (interim report ) 2012 年度風疹予防接種状況および抗体保有状況- 2012年度感染症流行予測調查(中 間報告). Infectious Agents Surveillance Report 34: 105-107.

7. Nardone A, Tischer A, Andrews N, Backhouse J, Theeten H, et al. (2008) Comparison of rubella seroepidemiology in 17 countries: Progress towards international disease control targets. Bulletin of the World Health Organization 86: 118-125.

8. Heggie AD, Robbins FC (1969) Natural Rubell Acquired After Birth. Am J Dis Child 118: $12-17$

9. Sherman FE, Michaels RH, Kenny FM (1965) Acute encephalopathy (encephalitis) complicating rubella. JAMA 192: 675-681. [Crossref]

10. William LB, Frank ES, Richard HM, Isabel LS, Jessica HL (1965) Purpura in congenita and acquired rubella. $N$ Engl J Med 273: 1362-1366. [Crossref]

11. Kato H, Imamura A, Sekiya N, Yanagisawa N, Suganuma A, et al. (2013) Medica Study of Cases Diagnosed as Rubella in Adults Hirofumi (成人における風疹の臨床 像についての検討). The journal of Japanese the Association for Infectious Diseases 87: 603-607.

12. Reef SE, Plotkin S, Cordero JF, Katz M, Cooper L, Schwartz B, Zimmerman-Swain L, Danovaro-Holliday MC, Wharton M. Preparing for elimination of congenital Rubella syndrome (CRS): summary of a workshop on CRS elimination in the United States (2000) Clin Infect Dis 31: 85-95. [Crossref]

13. National Institute of Infectious Diseases (2014) Reports of congenital rubella syndrome (先天性風しん症候群CRS の報告).

14. Ministry of Health Labour and Welfare. Spread enlightenment business of infection prevention of rubella (風しんの感染予防の普及啓発事業).

15. Ministry of Health Labour and Welfare. Demographic year estimate (人口動態統計 の年間推計)

16. Drummond MF, O'Brien B, Stoddart GL, Torrance GW (1997) Methods for the Economic Evaluation of Health Care Programmes. Second Edi. Oxford University Press: 206-207.

17. Centers for Disease Control and Prevention (CDC) (2014) Rubella. 
18. Patja A, Davidkin I, Kurki T, Kallio MJ, Valle M, et al. (2000) Serious adverse events after measles-mumps-rubella vaccination during a fourteen-year prospective followup. Pediatr Infect Dis J 19: 1127-1134. [Crossref]

19. National Institute of Infectious Diseases (2005) Guidelines for rubella vaccination (風 疹予防接種に関するガイドライン).

20. National Institute of Infectious Diseases (2013) Risk assessment second edition about the occurrence of rubella epidemic and congenital rubella syndrome (風疹流行および 先天性風疹症候群の発生に関するリスクアセスメント第二版) 1-7.

21. Ministry of Health Labour and Welfare. number of regular vaccination participants (定期の予防接種実施者数). [accessed 2015 Aug 19]. http://www.mhlw.go.jp/topics/ bcg/other $/ 5 . h t m l$

22. Statistic Bureau Ministry of Internal Affairs and Communications (2011) Basic Survey on Wage Structure (賃金構造基本統計調查).

23. Shiroiwa T (2013) A commentary on "Guideline for economic evaluation of healthcare technologies in Japan” (医療経済評価研究における分析手法に関するガイドライ ン」の解説). J Natl Inst Public Health 62: 590-598.

24. Tokyo Metropolitan Infectious Diseases Surveillance Center (2013) The rubella complication cases in Tokyo (東京都における風しん合併症事例).

25. Ministry of Health Labour and Welfare (2011) Survey on medical benefit costs (医療 給付費実態調査)
26. Ministry of Health Labour and Welfare (2011) Overview of Patient survey 2011 (平成 23 年患者調査の概要).

27. Ghidini A, Lynch L, York N (1993) Prenatal Diagnosis and Significance of Fetal Infections.

28. Japan Society of Perinatal and Neonatal Medicine (2014) Congenital rubella syndrome clinic manual (先天性風疹症候群CRS診療マニュアル)

29. Al-Awaidy S, Griffiths UK, Nwar HM, Bawikar S, Al-Aisiri MS, et al. (2006) Costs of congenital rubella syndrome (CRS) in Oman: evidence based on long-term follow-up of 43 children. Vaccine 24: 6437-6445. [Crossref]

30. National Institute of Infectious Diseases (2012) Rubella vaccination status and antibody prevalence in 2012.

31. Bullens D, Smets K, Vanhaesebrouck P (2000) Congenital Rubella Syndrome After Maternal Reinfection. Clin Pediatr (Phila) 39: 113-116. [Crossref]

32. Lieu T, Meltzer MI, Messonnier ML (2008) Guidance for Health Economics Studies Presented to the Advisory Committee on Immunization Practices (ACIP): 1-9.

33. Kernick DP (2003) Introduction to health economics for the medical practitioner Postgrad Med J 79: 147-150. [Crossref]

Copyright: (C2016 Itatani T. This is an open-access article distributed under the terms of the Creative Commons Attribution License, which permits unrestricted use, distribution, and reproduction in any medium, provided the original author and source are credited. 